\title{
Influência da taxa de crescimento e estro da co bertura no desempenho reprodutivo da leitoa*
}

\author{
RAFAEL KUMMER
}

\author{
Fernando Pandolfo Bortolozzo (Orientador - UFRGS) \\ Ivo Wentz (Co-Orientador - UFRGS) \\ Mari Lourdes Bernardi (Co-Orientadora - UFRGS)
}

Banca: Antônio Mario Penz Jr. (UFRGS), David Emilio Santos Neves de Barcellos (UFRGS), Guilherme Borchardt Neto (UNICRUZ).

\begin{abstract}
A inseminação artificial da leitoa é recomendada levando em consideração a idade, o peso, a espessura de toucinho e o ciclo estral no qual se encontra a fêmea. Entretanto, apesar dessas variáveis estarem correlacionadas, nem sempre todos esse índices são obtidos. A leitoa representa alto impacto nos dias-não-produtivos do plantel e é fundamental que seja inseminada no momento correto pois a longevidade e o desempenho reprodutivo da fêmea suína estão diretamente relacionados com o momento dessa inseminação. Esta tese foi dividida em três trabalhos, objetivando avaliar os efeito da idade, do peso, do estro da cobertura e da taxa de crescimento no desempenho reprodutivo da leitoa. O primeiro experimento foi realizado com o objetivo de determinar se leitoas que apresentam maiores taxas de crescimento e apresentam o peso mínimo recomendado para cobertura em uma idade mais precoce podem ser inseminadas sem apresentarem prejuízos reprodutivos ou uma maior taxa de descarte até o $3^{\circ}$ parto. Foram formados 3 grupos, conforme o peso e a idade na inseminação. O grupo 1 foi composto pelas fêmeas que apresentaram alta taxa de crescimento $(3700 \mathrm{~g} / \mathrm{dia})$ inseminadas com idade inferior a 210 dias. $\mathrm{O}$ grupo 2 foi formado também por leitoas que apresentaram alta taxa de crescimento ( $3700 \mathrm{~g})$ porém que foram inseminadas com idade igual ou superior a 210 dias. $O$ grupo 3 foi formado por fêmeas inseminadas com idade igual ou superior a 210 dias mas que apresentaram baixa taxa de crescimento ( $<700 \mathrm{~g} / \mathrm{dia}$ ). Houve um maior número de nascidos totais no primeiro parto para as fêmeas do grupo 2. Entretanto, analisando os 3 primeiros partos, não houve diferença no número médio de leitões produzidos (11,6 x 12,3 x 11,7), na taxa de parto $(87,1 \%$ x 88,7\% x 89,8\%) e na taxa de descarte $(30,0 \%$ x 25,3\% x 28,3\%) entre as fêmeas dos grupos 1,2 e 3 , respectivamente $(\mathrm{p}>0.05)$. O segundo experimento foi desenvolvido com o objetivo de avaliar se existia diferença na idade à puberdade, na taxa de ovulação e na sobrevivência embrionária de leitoas que apresentaram diferenças nas taxas de crescimento. Foram selecionadas 120 leitoas, aos 144 dias de idade, sendo formados 2 grupos, de acordo com a taxa de crescimento na seleção. O grupo 1 foi formado por 60 leitoas que apresentaram taxa de crescimento média de $576 \mathrm{~g} / \mathrm{d}$ e o grupo 2 por 60 fêmeas que apresentaram taxa de crescimento média de $722 \mathrm{~g} / \mathrm{d}$ na seleção. As fêmeas foram agrupadas em baias e estimuladas ao desencadeamento da puberdade com o auxílio de machos adultos. As leitoas foram inseminadas a partir de 50 dias após o início do manejo e foram abatidas 30 dias após, para análise das ovulações e do número de embriões. As fêmeas com maiores taxas de crescimento apresentaram puberdade mais precoce (156 x 163 dias; $\mathrm{p}<0.01)$ e menor porcentagem de anestro aos 190 dias de idade $(3,5 \%$ x 20,7\%; p<0.01). O terceiro experimento teve por objetivo avaliar a influência do estro da inseminação sobre o desempenho reprodutivo no primeiro parto de leitoas que não apresentaram mesmo peso e idade na inseminação. Foram formados 4 grupos, conforme os estros da inseminação, sendo que as leitoas inseminadas no $1^{\circ}$ estro apresentaram menor número de nascidos e menor taxa de parto que as leitoas inseminadas no $3^{\circ}$ e $4^{\circ}$ estros. Não houve diferença nas taxas de parto e no número de leitões nascidos entre as fêmeas inseminadas no $2^{\circ}, 3^{\circ}$ e $4^{\circ}$ estro. Conforme os resultados obtidos nos 3 experimentos, é possível concluir que leitoas podem ser inseminadas a partir do $2^{\circ}$ estro e aquelas que apresentam maiores taxas de crescimento têm puberdade mais precoce, menor porcentagem de anestro e podem ser inseminadas mais precocemente, sem prejuízos produtivos até o terceiro parto.
\end{abstract}

Descritores: leitoa, ganho de peso, puberdade, sobrevivência embrionária, leitegada.

Apresentada: 09 setembro 2005

*Tese de Doutorado n. 61 (Especialidade: Fisiopatologia da Reprodução). 93f. Programa de Pós-graduação em Ciências Veterinárias [www.ufrgs.br/ ppgcv], Faculdade de Veterinária, Universidade Federal do Rio Grande do Sul (UFRGS), Porto Alegre, RS/Brasil. CORRESPONDÊNCIA: R. Kummer [rafael.kummer@pic.com]. 


\title{
Influences of growth rate and time of mating on reproductive performance of gilts ${ }^{* *}$
}

\author{
RAFAEL KUMMER
}

\author{
Fernando Pandolfo Bortolozzo (Adviser - UFRGS) \\ Ivo Wentz (Co-Adviser - UFRGS) \\ Mari Lourdes Bernardi (Co-Adviser - UFRGS)
}

Committee: Antônio Mario Penz Jr. (UFRGS), David Emilio Santos Neves de Barcellos (UFRGS), Guilherme Borchardt Neto (UNICRUZ).

Recommendations for the timing of gilt insemination has been based on breed, age, weight, estrous cycle and backfat depth. Gilt insemination at the right time is necessary as it has a high impact on non-productive days and because the longevity and reproductive performance are correlated to this moment. This study was divided into three parts to analyse the effects of age, weight, oestrus mating and growth rate on reproductive performance of the gilts. The first experiment was to analyse if gilts which had a high growth rate (GR) could be mated in advance without a decrease in reproductive performance or an increase in cull rate over 3 farrowings. Gilts were divided into 3 groups according to weight and age at insemination. Group $1(n=168)$ had gilts with a GR = $700 \mathrm{~g} / \mathrm{d}$ and inseminated at $<210 \mathrm{~d}$. G2 $(\mathrm{n}=160)$ had gilts with a GR = $700 \mathrm{~g} / \mathrm{d}$ and inseminated at $=210 \mathrm{~d}$ and G3 $(\mathrm{n}=242)$ had gilts with a $\mathrm{GR}<700 \mathrm{~g} / \mathrm{d}$ and inseminated at $=210 \mathrm{~d}$. There was a higher total born at first farrowing in group 2, however, after evaluating three parity results there was no statistical difference in total born (11.6 x $12.3 \times 11.7)$, farrowing rates $(87.1 \%, 88.7 \%, 89.8 \%)$ and cull rates $(30 \%, \mathrm{x} 25.3 \%$ x $28.3 \%)$ among groups 1,2 and 3 , respectievely $(\mathrm{p}>0.05)$. The second experiment was to analyse if there is any difference in puberty age, ovulation rate and embryo survival rate among gilts with differences in GR during rearing. One hundred and twenty gilts were selected at 144 days of age and divided into two groups according to GR. Group one was made up of 60 gilts with a mean growth rate of 576 $\mathrm{g} / \mathrm{d}$ and group 2 of gilts with a mean growth rate of $722 \mathrm{~g} / \mathrm{d}$ at selection. Gilts were stimulated to puberty with a boar, inseminated around 50 days after the beginning of the experiment and were slaughtered 30 days after for ovulation and embryo survival analyses. Higher GR gilts showed puberty earlier $(156 \mathrm{x} 163$, p <0.01) with a lower anoestrus percentage $(3.5$ $\mathrm{x} 20.7 \%$; $\mathrm{p}$ 0.01). In the third study the importance of oestrus insemination on reproductive performance at first parity of gilts with the same weight and age at insemination was evaluated. In this study gilts were divided into 4 groups according to oestrus insemination. Gilts mated at first oestrus farrowed lower total born and had a decreased farrowing rate compared to gilts mated at third or fourth oestrus. There were no differences among gilts inseminated at second, third and fourth oestrus. According to the results gilts can be inseminated at second oestrus. Gilts with higher growth rate have precocious puberty, lower anoestrus percentage and can be mated earlier without decreasing productive results compared to other gilts.

Key words: gilt, weight gain, puberty, embryo survival, litter size. 